\title{
The Information and Bargaining Roles of Commercial Brokers When Investors Are Uninformed
}

\author{
Jonathan A. Wiley¹, Yu Liu², Liang Guo², Paul Gallimore ${ }^{3}$ \\ ${ }^{1}$ Department of Real Estate, J. Mack Robinson College of Business, Georgia State University, Atlanta, GA, USA \\ ${ }^{2}$ Department of Accounting and Finance, College of Business and Public Administration, California State University, \\ San Bernardino, CA, USA \\ ${ }^{3}$ School of Economics \& Finance, Massey Business School, Palmerston North, New Zealand \\ Email: jwiley@gsu.edu, yu.liu@csusb.edu,lguo@csusb.edu, P.Gallimore@massey.ac.nz
}

How to cite this paper: Wiley, J.A., Liu, Y., Guo, L. and Gallimore, P. (2019) The Information and Bargaining Roles of Commercial Brokers When Investors Are Uninformed. Theoretical Economics Letters, 9, 1651-1668.

https://doi.org/10.4236/tel.2019.95105

Received: May 8, 2019

Accepted: June 24, 2019

Published: June 27, 2019

Copyright ( 2019 by author(s) and Scientific Research Publishing Inc. This work is licensed under the Creative Commons Attribution International License (CC BY 4.0).

http://creativecommons.org/licenses/by/4.0/ (c) () Open Access

\begin{abstract}
Market outcomes are contrasted for uninformed investors with and without broker representation to evaluate the information role, and for parties opposing the uninformed (with and without representation) to evaluate the bargaining role. The setting is a sample of 17,000 office building transactions in more than 100 US markets, and the identification strategy for uninformed investors is based on the nonlocal clientele effect. Nonlocal investors buy high and sell low, paying significant premiums in acquisitions and accepting discounted offers in divestitures. Employing a commercial broker is found to have virtually zero impact on this disparity. Moreover, when the opposite party has broker representation, the degree of overpayment by nonlocal buyers is even higher. These findings are at odds with the conventional notion that brokers possess a high degree of specialized market knowledge which can be used to offset informational disadvantages suffered by their clients.
\end{abstract}

\section{Keywords}

Principal-Agent, Commercial Real Estate

\section{Introduction}

Real estate brokers are widely assumed to possess specialized market knowledge which can be commissioned to offset disadvantages faced by uninformed market participants. In this study, we empirically dissect the efficacy of brokerage intermediation for uninformed investors. The setting is commercial real estate 
(CRE), where assets are held for investment purpose rather than consumption. The identification strategy for an uninformed investor is based on geographic origin. Nonlocal investor clienteles persistently underperform in CRE markets: overpaying for purchases and selling assets at significant discounts to local players. Whether hiring a CRE broker has any impact on the outcome for nonlocal investors is the central focus of this study.

Nonlocal investors are buyers or sellers whose address is located in a different geographic market than the investment property. CoStar data includes around 17,000 transactions of office property for which investor address and investor type are available, covering 138 US markets during the period 1991 to 2013 Nonlocal investors represent a nontrivial component of the office market with roughly 30 percent of buyers and sellers classified as such. Outcomes for nonlocal investors have heightened relevance today as domestic funds pursue geographic diversification in their CRE portfolios, and foreign capital continues to flock to US markets responding to perceptions of lower risk and long-term capital preservation relative to alternative investment opportunities. Yet, evidence for underperformance by nonlocal investors suggests practical limitations to the theoretically-optimal diversification strategy.

Perhaps brokerage intermediation can resolve these issues if a CRE broker is able to provide their clients with specialized market information and bargaining expertise. However, brokerage compensation contracts may fail to align incentives with that of obtaining the best possible price for their clients. Existing literature focuses heavily on the search role of brokers, yet advancements in technology have increased informational transparency for market participants. Lacking from the literature is the evaluation of brokers who represent informed versus uninformed investors-potentially illuminating the informational role of brokers. Correspondingly, the bargaining role is revealed in market outcomes when the opposite party to a broker is informed versus uninformed.

To conduct the analysis, a propensity-score matching procedure is executed for each comparison set in order to minimize issues with sample heterogeneity and selection bias in CRE data. Four matched sample comparison sets are constructed on each side of the transaction. For purchases, prices paid by local buyers with broker representation are compared to those paid by local buyers without representation-to identify baseline brokerage intermediation effects for informed buyers. Nonlocal buyers are compared to each other, with and without representation, to estimate the impact of brokerage involvement for uninformed buyers. Transactions of unrepresented nonlocal buyers are compared to those of local buyers, who are also unrepresented, to quantify the nonlocal clientele effect that exists in the absence of brokers. Finally, outcomes for nonlocal buyers who have broker representation are compared to outcomes for represented local buyers to determine whether the nonlocal clientele effect differs when brokers are involved. Similarly for asset sales, the symmetric sequence of four-dimension comparison is provided. 
The next section provides background on the nonlocal clientele effect and brokerage intermediation in real estate markets. The third section explains the data used in this study and the empirical methodology. The fourth section discusses the empirical findings, and the final section provides concluding remarks.

\section{Background}

\section{A) Nonlocal Clienteles in Real Estate Markets}

Nonlocal investors in real estate markets suffer from informational disadvantages that distort their ability to obtain accurate asset valuations. Impacts from nonlocal investment can be severe enough to even produce localized asset price bubbles, as in the case of Japanese buyers converging on the Waialae-Kahala, Hawaii housing market during the late-1980s [1]. By nature, clientele effects are biased toward finding evidence of overpayment by uninformed buyers. If valuations by uninformed buyers were too low, few sellers would be willing to transact in the local asset market. Instead, the clientele effect appears once there is sufficient transaction activity by nonlocal buyers-each successfully outbidding the local competition. In the Waialae-Kahala neighborhood, waterfront homes doubled in value and homes prices on interior lots rose more than 50 percent from 1986 to 1987.

Studies for nonlocal investor clienteles include forest parcel sales in Adirondack Park [2], apartment rents paid by new residents [3], condominiums in Singapore [4], investment houses in Las Vegas [5], and house prices in Baton Rouge [6], Glasgow [7] and Florida [8]. Economic rationale for higher prices paid by nonlocal buyers in housing markets include higher search costs and informational disadvantages-formalized in the model by Turnbull and Sirmans [6]. Support for the explanation based on information asymmetry is documented by $\mathrm{Neo}$, Ong and $\mathrm{Tu}[4]$, who find that foreigners pay higher premiums for low-rise condominiums which are more heterogeneous and difficult to value than high-rise units. Anchoring is a more specific version of informational disadvantage where buyers from distant markets apply false reference points of asset values from their home market. Evidence supporting the anchoring hypothesis identifies that higher prices or rents for housing are paid by those who emanate from more expensive markets [2] [3] [8].

Apart from residential, evidence for premiums paid by nonlocal investors on CRE assets includes apartment complexes in Phoenix [9] and office buildings in more than 100 US markets [10]. Liu, Gallimore and Wiley [10] also consider the divestiture side of the investment, finding that nonlocals sell at a significant discount to similar assets sold by locals. Evidence from these two studies on CRE investment support both the anchoring and search cost explanations. Faced with mounting evidence of underperformance by nonlocal investors, the natural next question becomes: Why wouldn' $t$ nonlocal investors simply hire a CRE broker to eliminate the information disadvantage?

The nonlocal clientele effect in CRE presents an ideal context within which to investigate the ability of brokers to resolve information problems in heteroge- 
neous asset markets. As an investment good, CRE is valued primarily for its ability to generate cash flow-rather than for its consumption value, as occurs for housing. Nonlocal investors remain in their nonlocal offices during the holding period-rather than becoming local residents following the purchase, as occurs for homeowners. These aspects allow us to evaluate informational disadvantages on both purchase and sale sides of the transaction so that the effectiveness of brokerage involvement can be clarified. Transactions among uninformed investors can be compared, with and without brokerage representation, to transactions among informed investors; or when informed investors are matched against the uninformed.

\section{B) Brokerage Intermediation in Real Estate Markets}

Real estate brokers offer a wide range of services depending on which party to the transaction they represent. Listing brokers generally provide direct representation for the seller and offer information about the local property market, advising the seller in setting or changing the listing price, marketing and showing the property, negotiating the sale price, and assisting the seller with the closing process. Buyer brokers-who contractually represent the buyer's interest-may also provide informational, search, bargaining, and facilitating roles. Informational transparency has increased for real estate assets with widespread adoption of property search technology in recent years, such as the MLS provides for the housing sector. Yet, it remains a widely-held belief that real estate brokers possess a high degree of specialized market knowledge that can act to offset informational disadvantages faced by either party, when represented. As Han and Strange [11] point out: "Quite naturally, the value of real estate brokers should be particularly large for unsophisticated buyers and sellers with limited knowledge and experience of housing markets".

There are issues with incentive alignment and brokerage compensation for both the listing broker and the buyer broker. In the United States, the conventional brokerage fee is structured as a percentage commission rate (typically around 6 percent of the sale price), and the listing agreement defines the expiration date. The listing broker's incentive is then to ensure that the property sells within the contract period [12], whereas search costs may be significantly higher for the seller than for the broker. In addition, a one percentage point increase in the sale price has a much smaller impact on the listing broker's compensation than it does on the seller's net gain from sale. These conditions are favorable for a listing broker who is able to influence the seller to set a lower listing price, or accept a lower offer from a potential buyer; both actions increase the probability of sale and reduce expected search effort [13]. In practice, real estate brokers are observed to achieve significantly higher transaction prices on their own property than they do for their clients-exposing conflicts of interest in the principal-agent model for real estate brokerage [14] [15].

Buyer brokers have incentives to minimize search costs per successful transaction. The first-stage objective is to search until a property is found that sufficiently satisfies buyer criteria. Once an acceptable match is found, the objective 
then becomes to close the deal. If a buyer broker can convince their client to increase the offer, it increases the probability of concluding the search and linearly increases brokerage compensation [16]. There is some evidence that higher percentage commission rates on buyer brokerage arrangements lead to higher prices paid by the buyer [17].

Under dual agency, the brokerage firm represents both parties to the transaction-with conflicting implications for the marketing outcome. Brokers involved in dual agency are uniquely positioned to possess privileged information about the reservation prices of both parties. On the one hand, such information could be exploited to maximize sale price and broker compensation. On the other hand, pressure toward a lower price increases the likelihood of successful agreement during the bargaining stage. Accordingly, dual agency heightens litigation risk for the participating brokerage firm in the event that either party feels unfairly treated after closing. Gardiner, Heisler, Kallberg and Liu [18] find that dual agency results in lower selling prices, but that the discount is dramatically reduced following enactment of a law for mandatory disclosure of agency relationships.

In the brokerage intermediation literature, almost all studies are based on housing data. One exception is Hardin, Johnson and $\mathrm{Wu}$ [19], who focus on apartment transactions. They find limited to no evidence for brokerage effects and contend that its impact is likely minimal for income-producing assets due to a higher degree of investor sophistication and greater informational transparency.

In the present study, we challenge these notions. Not all CRE investors are highly sophisticated (e.g. see earlier discussion for nonlocal clienteles) and the assets involved have highly heterogeneous attribute sets, distorting the valuation process. Informational transparency is arguably no greater in the commercial sector than it is for houses. CRE assets are thinly traded and detailed information about transactions is primarily available through private vendors, such as CoStar and Real Capital Analytics, with subscriptions that can be cost-prohibitive for even some commercial brokers to obtain. Whereas housing data in the modern era are essentially freely available to the general public through online platforms such as Zillow and Trulia. As a consequence of noisy asset values and arguablyless informational transparency in the CRE sector, it is possible that even brokers themselves do not always possess a high degree of specialized market knowledge that could be used to offset informational disadvantages.

An alternative view is that the CRE broker possesses information primarily limited to the seller's reservation price (when serving as the listing broker), the buyer's reservation price (as the buyer broker), or both (under dual agency). The broker's objective is to successfully close a deal within the specified contract period of the brokerage arrangement. Success is measured relative to the client's expectation, rather than some unobservable market value. Uninformed investors generate expected values for the asset that are subject to greater variance and potentially biased relative to expectations formed by informed investors. As a 
consequence, a property is expected to sell at a higher price when an informed seller matches with an uninformed buyer; or at a lower price whenever an uninformed seller matches with an informed buyer. If brokers play an important information role, then brokerage intermediation should significantly reduce price disparity in mismatched transactions. If, instead, brokers primarily negotiate relative to their client's expectation, then brokers bargaining capabilities are vulnerable. Successful bargaining by brokers should result in informed investors receiving better prices for their assets when matched against uninformed investors. Dual agency scenarios potentially mitigate the exposure for uninformed participants. If litigation risk is relevant to the broker's expected cost function, then dual agency brokers-who are likely informed about both sets of reservation prices-might steer negotiations toward a price where neither party appears disadvantaged.

The central motivation in this study is to explore the interaction of brokerage intermediation when CRE investors are uninformed. The identification strategy for uninformed investors is based on informational disadvantages faced by nonlocal clienteles who tend to underperform in the office market. We evaluate the roles of both listing brokers and buyer brokers, as well as dual agency scenarios. The lens through which we examine these effects applies a propensity-score matching technique to limit sample selection bias and to provide this comparison for CRE assets that have similar characteristics. Brokerage intermediation effects are compared for properties bought and sold by informed market participants, as well as for properties bought and sold by uninformed participants. This is the first research study to evaluate the interaction of broker involvement for nonlocal clientele effects in CRE investment markets.

\section{Data \& Methodology}

CRE transactions data used in this study are from the CoStar COMPs ${ }^{\circledR}$ database, which provides nationwide (US) coverage for commercial property transactions. The purchase samples used to examine brokerage intermediation and nonlocal investor effects consists of 17,157 office property transactions; the sales sample contains 16,996 observations ${ }^{1}$. Transaction dates range from 1991 through 2013, with observations taken from 138 US office markets ${ }^{2}$. In order to be included in

${ }^{1}$ The number of observations used in the full sample does not include observations that are more than three standard deviations beyond the sample mean for each of the dependent variables considered in the empirical analysis. An alternative approach to the propensity-score matching procedure applies both the trimmed and untrimmed full samples, resulting in empirical results that are qualitatively consistent in sign and significance with each of the results reported in this study.

${ }^{2}$ There are totally 138 markets identified on CoStar. The markets are: Albany/Schenectady/Troy, Albuquerque, Anchorage, Asheville, Atlanta, Augusta/Richmond County, Austin, Bakersfield, Baltimore, Baton Rouge, Beaumont/Port Arthur, Birmingham, Boise City/Nampa, Boston, Bremerton/Silverdale, Brownsville/Harlingen, Buffalo/Niagara Falls, Charleston WV, Charleston/N Charleston, Charlotte, Chattanooga, Chicago, Cincinnati/Dayton, Cleveland, Colorado Springs, Columbia, Columbus, Columbus GA, Corpus Christi, Dallas/Ft Worth, Davenport/Moline/Rock Island, Deltona/Daytona Beach, Denver, Des Moines, Detroit, Duluth, East Bay/Oakland, El Paso, Erie, Evansville, Fayetteville, Fayetteville/Springdale/Rogers, Fort Smith, Fort Wayne, Fresno, Green Bay, Greensboro/Winston-Salem, Greenville/Spartanburg, Hampton Roads, Hartford, Hawaii, Houston, 
the sample, each observation is required to have information available in data fields for investor identity and investor address, along with all other variables relevant to the analysis.

Table 1 presents summary statistics for the purchase samples. Panel A outlines the samples of local and nonlocal buyers, along with subsamples for buyers with broker representation compared to the propensity-score matched subsample of buyers who were unrepresented in the transaction. For local buyers, the average purchase price is $\$ 140$ per square foot for a 39-year old structure with 33,930 square feet of rentable building area on a 2 acre lot. Given the relatively high age and small structure size, it is not surprising that just 6 percent of the assets acquired by local buyers are Class A, 46 percent are Class B, while 48 percent of the samples are Class C. Among the 12,103 observations of acquisitions by local office buyers, 37 percent had buyer representation during the transaction. Represented buyers purchased slightly smaller properties (26,135 square feet on average), but at a higher price ( $\$ 144$ per square foot).

In order to provide a meaningful and accurate comparison, a propensity-score matched sample is constructed. A probit model is estimated for the probability that an office building selected by a local buyer will involve buyer representation. The probit model includes variables for land area, building size, property age, along with indicators for property class, multi-tenancy, buyer classification ${ }^{3}$, acquisition timing, geographic market, and sale conditions ${ }^{4}$. For each observation of a local buyer who purchased an office building with buyer representation, an observation for a local buyer who did not have buyer representation is collected. Huntington/Ashland, Huntsville, Indianapolis, Inland Empire (California), Jackson, Jacksonville (Florida), Kansas City, Killeen/Temple/Fort Hood, Kingsport/Bristol/Bristol, Knoxville, Lafayette, Las Vegas, Lexington/Fayette, Lincoln, Little Rock/N Little Rock, Long Island (New York), Los Angeles, Louisville, Lubbock, Marin/Sonoma, McAllen/Edinburg/Pharr, Memphis, Milwaukee/Madison, Minneapolis/St Paul, Mobile, Montgomery, Myrtle Beach/Conway, Nashville, New Orleans/Metairie/Kenner, New York City, Northern New Jersey, Ocala, Oklahoma City, Olympia, Omaha/Council Bluffs, Orange County (California), Orlando, Pensacola, Peoria, Philadelphia, Phoenix, Pittsburgh, Port St Lucie/Fort Pierce, Portland, Portland/South Portland, Providence, Raleigh/Durham, Reno/Sparks, Richmond VA, Roanoke, Rochester, Sacramento, Salinas, Salt Lake City, San Antonio, San Diego, San Francisco, San Luis Obispo/Paso Robles, Santa Barbara/Sta Maria/Goleta, Santa Cruz/Watsonville, Savannah, Seattle/Puget Sound, Shreveport/Bossier City, South Bay/San Jose, South Bend/Mishawaka, South Florida, Southwest Florida, Spokane, Springfield, St. Louis, Stockton/Modesto, Syracuse, Tallahassee, Tampa/St Petersburg, Toledo, Tucson, Tulsa, Utica/Rome, Visalia/Porterville, Washington, DC, West Michigan, Westchester/So Connecticut, Wichita, Wilmington, Yakima, and Youngstown/Warren/Boardman.

${ }^{3}$ Investor types listed in CoStar include Bank/Finance, Corporate, National Developer, Regional Developer, Educational, Endowment, Equity Funds, Government, Individual, Insurance, Investment Manager, Listed Fund, Medical, Nonprofit, Other Private, Other Unknown Institution, Pension Fund, Private REITs, REITs, Religious, REOC, Sovereign, Special, Tenants, and Trust.

${ }^{4}$ The list of possible sale conditions identified by CoStar includes 1031 exchange, assemblage, auction sale, bankruptcy sale, build-to-suit, building contamination issue, building in shell condition, business value added, condo conversion, court appointed sale, debt assumption, deed restriction, deferred maintenance, direct exchange, distress sale, double escrow, estate/probate sale, excess land, exercise of option, expansion, ground lease (leased fee simple), ground lease (leasehold), high vacancy property, historical site, land contract, lease option, note purchase, partial interest transfer, purchase by tenant, recapitalization, redevelopment project, REO sale, rolling option/takedown, sale leaseback, short sale, and soil contamination issue. An alternative approach is to include only transactions that occur under normal sale conditions. 
Table 1. Summary statistics: Purchase samples.

\begin{tabular}{|c|c|c|c|c|c|c|c|c|c|c|c|c|}
\hline \multirow{4}{*}{$\begin{array}{c}\text { Panel A } \\
\text { Observations } \\
\text { Variable }\end{array}$} & \multicolumn{6}{|c|}{ Local Buyers } & \multicolumn{6}{|c|}{ Nonlocal Buyers } \\
\hline & \multicolumn{2}{|c|}{ Full sample } & \multicolumn{2}{|c|}{ Represented } & \multicolumn{2}{|c|}{ Unrepresented $^{\dagger}$} & \multicolumn{2}{|c|}{ Full sample } & \multicolumn{2}{|c|}{ Represented } & \multicolumn{2}{|c|}{ Unrepresented $^{\dagger}$} \\
\hline & \multicolumn{2}{|c|}{12,103} & \multicolumn{2}{|c|}{4512} & \multicolumn{2}{|c|}{4512} & \multicolumn{2}{|c|}{5054} & \multicolumn{2}{|c|}{1309} & \multicolumn{2}{|c|}{1309} \\
\hline & Mean & $(S t d d e v)$ & Mean & $(S t d d e v)$ & Mean & $(S t d d e v)$ & Mean & (Std dev) & Mean & $(S t d d e v)$ & Mean & (Std dev) \\
\hline Sale price $(\$ / S F)$ & 140 & (122) & 144 & (120) & 138 & (122) & 168 & (132) & 170 & (133) & 182 & (143) \\
\hline Land area (SF) & 87,382 & $(379,183)$ & 77,505 & $(185,781)$ & 78,054 & $(214,476)$ & 193,458 & $(523,516)$ & 150,690 & $(261,126)$ & 171,540 & $(320,831)$ \\
\hline Size (SF) & 33,930 & $(102,854)$ & 26,135 & $(66,099)$ & 30,628 & $(95,586)$ & 97,639 & $(176,333)$ & 66,752 & $(132,351)$ & 82,396 & $(145,767)$ \\
\hline Age (years) & 39 & (31) & 38 & (30) & 40 & (31) & 27 & (24) & 26 & $(21)$ & 28 & (26) \\
\hline Class A & 0.06 & $(0.2)$ & 0.04 & $(0.2)$ & 0.04 & $(0.2)$ & 0.25 & $(0.4)$ & 0.16 & $(0.4)$ & 0.18 & $(0.4)$ \\
\hline Class B & 0.46 & $(0.5)$ & 0.50 & $(0.5)$ & 0.48 & $(0.5)$ & 0.54 & $(0.5)$ & 0.62 & (0.5) & 0.60 & $(0.5)$ \\
\hline Class C & 0.48 & $(0.5)$ & 0.46 & $(0.5)$ & 0.48 & $(0.5)$ & 0.21 & $(0.4)$ & 0.22 & $(0.4)$ & 0.22 & $(0.4)$ \\
\hline Multi-tenant & 0.70 & $(0.5)$ & 0.69 & $(0.5)$ & 0.69 & $(0.5)$ & 0.80 & $(0.4)$ & 0.78 & $(0.4)$ & 0.79 & $(0.4)$ \\
\hline Market time & 382 & (379) & 386 & (376) & 386 & (392) & 252 & (290) & 281 & (304) & 245 & (283) \\
\hline Buyer rep & 0.37 & $(0.5)$ & 1 & (0) & 0 & (0) & 0.26 & $(0.4)$ & 1 & (0) & 0 & (0) \\
\hline Seller rep & 0.64 & $(0.5)$ & 0.92 & $(0.3)$ & 0.51 & $(0.5)$ & 0.61 & $(0.5)$ & 0.91 & $(0.3)$ & 0.60 & $(0.5)$ \\
\hline Same rep & 0.12 & $(0.3)$ & 0.33 & $(0.5)$ & 0 & (0) & 0.11 & $(0.3)$ & 0.42 & $(0.5)$ & 0 & (0) \\
\hline Nonlocal & 0 & (0) & 0 & (0) & 0 & (0) & 1 & (0) & 1 & (0) & 1 & (0) \\
\hline \multirow[t]{2}{*}{ Panel B } & \multicolumn{6}{|c|}{ Represented Buyers } & \multicolumn{6}{|c|}{ Unrepresented Buyers } \\
\hline & \multicolumn{2}{|c|}{ Full sample } & \multicolumn{2}{|c|}{ Nonlocal } & \multicolumn{2}{|c|}{ Local $^{\dagger}$} & \multicolumn{2}{|c|}{ Full sample } & \multicolumn{2}{|c|}{ Nonlocal } & \multicolumn{2}{|c|}{ Local $^{\dagger}$} \\
\hline Observations & \multicolumn{2}{|c|}{5821} & \multicolumn{2}{|c|}{1309} & & 309 & & ,336 & & 745 & & 745 \\
\hline Variable & Mean & $(S t d d e v)$ & Mean & $(S t d d e v)$ & Mean & $(S t d d e v)$ & Mean & (Std dev) & Mean & (Std dev) & Mean & (Std dev) \\
\hline Sale price $(\$ / S F)$ & 150 & (124) & 170 & (133) & 153 & (120) & 147 & (126) & 167 & (132) & 141 & (124) \\
\hline Land area (SF) & 93,962 & $(207,388)$ & 150,690 & $(261,126)$ & 129,059 & $(253,407)$ & 131,296 & $(506,624)$ & 208,407 & $(587,543)$ & 136,281 & $(618,932)$ \\
\hline Size (SF) & 35,269 & $(87,239)$ & 66,752 & $(132,351)$ & 48,743 & $(92,339)$ & 61,646 & $(149,293)$ & 108,435 & $(188,134)$ & 59,530 & $(142,737)$ \\
\hline Age (years) & 35 & (29) & 26 & $(21)$ & 28 & $(22)$ & 36 & (30) & 27 & $(25)$ & 34 & (28) \\
\hline Class A & 0.07 & $(0.3)$ & 0.16 & $(0.4)$ & 0.10 & $(0.3)$ & 0.14 & $(0.4)$ & 0.28 & $(0.5)$ & 0.13 & $(0.3)$ \\
\hline Class B & 0.53 & $(0.5)$ & 0.62 & $(0.5)$ & 0.63 & $(0.5)$ & 0.46 & $(0.5)$ & 0.52 & $(0.5)$ & 0.52 & $(0.5)$ \\
\hline Class C & 0.40 & $(0.5)$ & 0.22 & $(0.4)$ & 0.27 & $(0.4)$ & 0.39 & $(0.5)$ & 0.20 & $(0.4)$ & 0.35 & $(0.5)$ \\
\hline Multi-tenant & 0.71 & $(0.5)$ & 0.78 & $(0.4)$ & 0.78 & $(0.4)$ & 0.74 & $(0.4)$ & 0.81 & $(0.4)$ & 0.77 & $(0.4)$ \\
\hline Market time & 364 & (365) & 281 & (304) & 350 & (380) & 252 & (290) & 281 & (304) & 353 & (381) \\
\hline Buyer rep & 1 & (0) & 1 & (0) & 1 & (0) & 0 & (0) & 0 & (0) & 0 & (0) \\
\hline Seller rep & 0.92 & $(0.3)$ & 0.91 & $(0.3)$ & 0.89 & $(0.3)$ & 0.48 & $(0.5)$ & 0.51 & $(0.5)$ & 0.46 & (0.5) \\
\hline Same rep & 0.35 & $(0.5)$ & 0.42 & $(0.5)$ & 0.36 & $(0.5)$ & 0 & (0) & 0 & (0) & 0 & (0) \\
\hline Nonlocal & 0.22 & $(0.4)$ & 1 & (0) & 0 & (0) & 0.33 & $(0.5)$ & 1 & (0) & 0 & (0) \\
\hline
\end{tabular}

${ }^{\dagger}$ Based on propensity-score matched sample. Notes: This table presents summary statistics for the purchase samples, including the sample mean (Mean) and standard deviation (Std dev) in parentheses. Panel A presents the comparison between Local Buyers and Nonlocal Buyers, partitioned into subsamples of buyers who were Represented by brokers or Unrepresented in the transaction. Unrepresented subsamples are generated from propensity-score matched samples. Panel B provides the comparison between Represented and Unrepresented Buyers, partitioned into subsamples of Nonlocal and Local buyers. Subsamples of Local buyers are produced from propensity-score matched samples. Variable definitions: Sale price is the transaction price for the office property, in US dollars, divided by Size. Land area is the gross square footage (SF) of the lot. Size is the rentable building area, measured in square feet (SF). Age is structure age, measured in years relative to the transaction date. Class A, Class B, and Class C are indicator variables taking on a value of one for the respective property class and zero otherwise. Multi-tenant is an indicator variable for properties that are not designed to be fully-occupied by a single tenant. Market time is the listing duration, in calendar days. Buyer rep is an indicator variable for buyers who had broker representation in the transaction. Seller rep is an indicator for use of a listing agent. Same rep is an indicator variable for Buyer rep and Seller rep from the same brokerage company for the transaction. Nonlocal is an indicator variable for buyers having a company address in a different geographic market than the asset. 
The matching process is carried out based on a one-to-one, nearest-neighbor propensity score matching with replacement. Summary statistics for the matched sample of unrepresented local buyers are also shown in Table 1.

The analogous sequence is executed to produce matched samples for unrepresented nonlocal buyers in Panel A, as well as for represented buyers with local addresses (matched to transactions that have similar attributes to those purchased by represented buyers with nonlocal addresses), and for unrepresented buyers with local addresses in Panel B of Table 1. Results from the probit estimations for the propensity scores are reported in Appendix Table A1. Generally, nonlocal investors are more likely to select newer, larger, and Class A office buildings. As a result of the matching procedure, the matched sample control groups for each comparison set have highly similar physical attributes, locational identities, investor types, and occur with similar market timing relative to the respective subject group.

By constructing the comparison samples for the empirical test in this manner, the results in this study will reveal 1) whether broker representation has an impact on purchase prices for local buyers, 2) whether representation impacts prices paid by nonlocal buyers, 3) whether nonlocal origin impacts prices paid by buyers with broker representation, and 4) whether nonlocal origin impacts price for unrepresented buyers. In addition to purchases, this study considers the impact on exit price obtained by local and nonlocal sellers, depending on whether broker representation is involved or not. Summary statistics for the sales samples are provided in Table 2, and the matched samples are produced from the identical procedure as previously discussed for the purchase samples.

Once the matched sampling procedures are applied, the next step in the empirical analysis estimates a hedonic regression with transaction price per square foot (Sale price), logged, as the dependent variable. The model is written as:

$$
\begin{aligned}
\ln (\text { Sale price })= & \beta_{0}+\beta_{1} \cdot \ln (\text { Land area })+\beta_{2} \cdot \ln (\text { Size })+\beta_{3} \cdot \ln (\text { Age }) \\
& +\beta_{4} \cdot \text { Class } \mathrm{A}+\beta_{5} \cdot \text { Class } \mathrm{B}+\beta_{6} \cdot \text { Multi-tenant }+\beta_{7} \cdot \ln (\text { Market time }) \\
& +\beta_{8} \cdot \text { Buyer rep }+\beta_{9} \cdot \text { Same rep }+\beta_{10} \cdot \text { Seller rep }+\beta_{11} \cdot \text { Nonlocal } \\
& +\gamma \cdot X+\delta \cdot T+\eta \cdot C+\theta \cdot M+\varepsilon .
\end{aligned}
$$

Land area, Size, Age, and Market time are logged. Class A and Class B are indicator variables for property class. Multi-tenant is an indicator variable for multi-tenant office assets. Buyer rep and Seller rep are indicator variables for broker representation of the respective parties. Same rep indicates that both parties were represented by brokers from the same firm. Nonlocal is an indicator variable for investors whose address is located in a different geographic market than the asset. Nonlocal identifies buyers in the purchase samples and sellers in the sales samples. $X$ is a matrix of control variables for investor classification. $T$ is a matrix of indicator variables for calendar year of the transaction date. $C$ is a matrix of control variables for unique sale conditions. $M$ is a matrix of geographic market indicator variables. $\gamma, \delta, \eta$, and $\theta$ are vectors of parameters for 
Table 2. Summary statistics: Sales samples.

\begin{tabular}{|c|c|c|c|c|c|c|c|c|c|c|c|c|}
\hline \multirow{2}{*}{ Panel A } & \multicolumn{6}{|c|}{ Local Sellers } & \multicolumn{6}{|c|}{ Nonlocal Sellers } \\
\hline & \multicolumn{2}{|c|}{ Full sample } & \multicolumn{2}{|c|}{ Represented } & \multicolumn{2}{|c|}{ Unrepresented $^{\dagger}$} & \multicolumn{2}{|c|}{ Full sample } & \multicolumn{2}{|c|}{ Represented } & \multicolumn{2}{|c|}{ Unrepresented $^{\dagger}$} \\
\hline Observations & \multicolumn{2}{|c|}{11,540} & \multicolumn{2}{|c|}{4053} & \multicolumn{2}{|c|}{4053} & \multicolumn{2}{|r|}{5456} & \multicolumn{2}{|c|}{1581} & \multicolumn{2}{|r|}{1581} \\
\hline Variable & Mean & $(S t d d e v)$ & Mean & $(S t d d e v)$ & Mean & $(S t d d e v)$ & Mean & $(S t d d e v)$ & Mean & $(S t d d e v)$ & Mean & $(S t d d e v)$ \\
\hline Sale price $(\$ / S F)$ & 147 & (124) & 148 & (119) & 151 & (129) & 141 & (119) & 148 & (120) & 151 & (129) \\
\hline Land area (SF) & 112,937 & $(1,619,026)$ & 92,792 & $(266,899)$ & 169,364 & $(2,714,743)$ & 156,631 & $(350,495)$ & 149,793 & $(241,252)$ & 167,219 & $(309,256)$ \\
\hline Size (SF) & 39,566 & $(122,076)$ & 40,422 & $(133,067)$ & 43,862 & $(128,947)$ & 79,324 & $(145,773)$ & 75,786 & $(129,097)$ & 92,317 & $(173,109)$ \\
\hline Age (years) & 39 & (32) & 39 & (32) & 38 & (31) & 30 & (26) & 31 & (26) & 31 & (27) \\
\hline Class A & 0.08 & $(0.3)$ & 0.08 & $(0.3)$ & 0.09 & $(0.3)$ & 0.20 & $(0.4)$ & 0.20 & $(0.4)$ & 0.21 & $(0.4)$ \\
\hline Class B & 0.46 & $(0.5)$ & 0.46 & $(0.5)$ & 0.47 & $(0.5)$ & 0.52 & $(0.5)$ & 0.51 & $(0.5)$ & 0.50 & $(0.5)$ \\
\hline Class C & 0.46 & $(0.5)$ & 0.46 & $(0.5)$ & 0.44 & $(0.5)$ & 0.27 & $(0.5)$ & 0.29 & $(0.5)$ & 0.29 & $(0.5)$ \\
\hline Multi-tenant & 0.71 & $(0.5)$ & 0.72 & $(0.5)$ & 0.73 & $(0.4)$ & 0.77 & $(0.4)$ & 0.76 & $(0.4)$ & 0.77 & $(0.4)$ \\
\hline Market time & 376 & (374) & 380 & (366) & 379 & (419) & 287 & $(318)$ & 308 & (336) & 243 & (279) \\
\hline Buyer rep & 0.35 & $(0.5)$ & 0.48 & (1) & 0.08 & (0) & 0.35 & $(0.5)$ & 0.43 & $(0.5)$ & 0.09 & $(0.3)$ \\
\hline Seller rep & 0.65 & $(0.5)$ & 1 & (0) & 0 & (0) & 0.71 & $(0.5)$ & 1 & (0) & 0 & (0) \\
\hline Same rep & 0.12 & $(0.3)$ & 0.18 & $(0.4)$ & 0 & (0) & 0.13 & $(0.3)$ & 0.17 & $(0.4)$ & 0 & (0) \\
\hline Nonlocal & 0 & (0) & 0 & (0) & 0 & (0) & 1 & $(0)$ & 1 & (0) & 1 & (0) \\
\hline \multirow[t]{2}{*}{ Panel B } & \multicolumn{6}{|c|}{ Represented Sellers } & \multicolumn{6}{|c|}{ Unrepresented Sellers } \\
\hline & \multicolumn{2}{|c|}{ Full sample } & \multicolumn{2}{|c|}{ Nonlocal } & \multicolumn{2}{|c|}{ Local $^{\dagger}$} & \multicolumn{2}{|c|}{ Full sample } & \multicolumn{2}{|c|}{ Nonlocal } & \multicolumn{2}{|c|}{ Local $^{\dagger}$} \\
\hline Observations: & \multicolumn{2}{|c|}{11,362} & \multicolumn{2}{|c|}{3875} & & 3875 & & 5634 & & 581 & & 1581 \\
\hline Variable & Mean & $(S t d d e v)$ & Mean & $(S t d \mathrm{dev})$ & Mean & $(S t d d e v)$ & Mean & $(S t d d e v)$ & Mean & $(S t d d e v)$ & Mean & $(S t d d e v)$ \\
\hline Sale price $(\$ / S F)$ & 142 & (119) & 137 & (114) & 151 & (121) & 151 & (129) & 151 & (129) & 151 & (123) \\
\hline Land area $(\mathrm{SF})$ & 106,237 & $(280,731)$ & 152,311 & $(365,938)$ & 117,277 & $(285,215)$ & 168,762 & $(2,308,286)$ & 167,219 & $(309,256)$ & 196,450 & $(1,199,055)$ \\
\hline Size (SF) & 49,785 & $(124,508)$ & 74,023 & $(132,677)$ & 57,608 & $(153,733)$ & 57,459 & $(144,361)$ & 92,317 & $(173,109)$ & 73,317 & $(178,073)$ \\
\hline Age (years) & 36 & (30) & 30 & (25) & 33 & (28) & 36 & (30) & 31 & (27) & 34 & (29) \\
\hline Class A & 0.12 & $(0.3)$ & 0.20 & $(0.4)$ & 0.13 & $(0.3)$ & 0.12 & $(0.3)$ & 0.21 & $(0.4)$ & 0.16 & $(0.4)$ \\
\hline Class B & 0.48 & $(0.5)$ & 0.53 & $(0.5)$ & 0.52 & $(0.5)$ & 0.48 & $(0.5)$ & 0.50 & $(0.5)$ & 0.51 & $(0.5)$ \\
\hline Class C & 0.40 & $(0.5)$ & 0.27 & $(0.4)$ & 0.35 & $(0.5)$ & 0.40 & $(0.5)$ & 0.29 & $(0.5)$ & 0.34 & $(0.5)$ \\
\hline Multi-tenant & 0.72 & $(0.5)$ & 0.77 & $(0.4)$ & 0.73 & $(0.4)$ & 0.74 & $(0.4)$ & 0.77 & $(0.4)$ & 0.77 & $(0.4)$ \\
\hline Market time & 348 & (355) & 290 & (320) & 342 & (350) & 345 & (394) & 243 & (279) & 362 & (466) \\
\hline Buyer rep & 0.49 & $(0.5)$ & 0.46 & $(0.5)$ & 0.50 & $(0.5)$ & 0.08 & $(0.3)$ & 0.09 & $(0.3)$ & 0.08 & $(0.3)$ \\
\hline Seller rep & 1 & $(0)$ & 1 & (0) & 1 & (0) & 0 & (0) & 0 & (0) & 0 & (0) \\
\hline Same rep & 0.18 & $(0.4)$ & 0.18 & $(0.4)$ & 0.19 & $(0.4)$ & 0 & (0) & 0 & (0) & 0 & (0) \\
\hline Nonlocal & 0.34 & $(0.5)$ & 1 & (0) & 0 & (0) & 0.28 & $(0.5)$ & 1 & (0) & 0 & (0) \\
\hline
\end{tabular}

${ }^{\dagger}$ Based on propensity-score matched sample. Notes: This table presents summary statistics for the sales samples, including the sample mean (Mean) and standard deviation (Std dev) in parentheses. Panel A presents the comparison between Local Sellers and Nonlocal Sellers, partitioned into subsamples of sellers who were represented by brokers or Unrepresented in the transaction. Unrepresented subsamples are generated from propensity-score matched samples. Panel B provides the comparison between Represented and Unrepresented Sellers, partitioned into subsamples of Nonlocal and Local sellers. Subsamples of Local sellers are produced from propensity-score matched samples. All variables are defined in the notes to Table 1. 
fixed effects. Empirical results for the estimation of Equation (1) for four purchase samples and four sales samples are discussed in the next section.

\section{Results}

Table 3 presents results from the purchase samples using propensity-score matching to estimate the effect of broker representation and buyer origin on prices paid for office buildings. Reading results from left-to-right, the first set is for the sample of local buyers. Prices paid by local buyers who have broker representation are compared to those in a matched sample of similar assets purchased by local buyers who were unrepresented during the transaction. $\mathrm{Cu}$ riously, the presence of buyer representation is associated with higher prices paid. Represented buyers overpay by an estimated 10.7 percent relative to similar assets (coefficient on Buyer rep). Thus, even after carefully controlling each measurable difference and applying the propensity-score matching procedure, buyer representation appears to make matters worse.

Table 3. Estimated price effects: Purchase samples.

\begin{tabular}{|c|c|c|c|c|c|c|c|c|c|c|c|c|}
\hline \multirow{3}{*}{$\begin{array}{c}\text { Sample } \\
\text { Variable } \\
\text { Constant }\end{array}$} & \multicolumn{3}{|c|}{ Local Buyers } & \multicolumn{3}{|c|}{ Nonlocal Buyers } & \multicolumn{3}{|c|}{ Represented } & \multicolumn{3}{|c|}{ Unrepresented } \\
\hline & \multicolumn{2}{|c|}{ Coefficient } & \multirow{2}{*}{$\frac{\text { t-stat }}{33.2}$} & \multicolumn{2}{|c|}{ Coefficient } & \multirow{2}{*}{$\frac{\text { t-stat }}{16.1}$} & \multicolumn{2}{|c|}{ Coefficient } & \multirow{2}{*}{$\frac{\text { t-stat }}{23.3}$} & \multicolumn{2}{|c|}{ Coefficient } & \multirow{2}{*}{$\frac{\text { t-stat }}{26.6}$} \\
\hline & 6.525 & $* * *$ & & 6.884 & $* * *$ & & 6.290 & $* * *$ & & 6.884 & $* * *$ & \\
\hline $\ln$ (Land area) & -0.007 & & -0.9 & -0.088 & $* * *$ & -5.5 & -0.076 & $* * *$ & -5.6 & -0.075 & $* * *$ & -6.5 \\
\hline $\ln ($ Size $)$ & -0.200 & $* * *$ & -19.9 & -0.049 & $* * *$ & -2.7 & -0.079 & $* * *$ & -4.7 & -0.068 & $* * *$ & -5.0 \\
\hline $\ln$ (Age) & -0.146 & $* * *$ & -15.2 & -0.153 & $* * *$ & -7.9 & -0.162 & $* * *$ & -10.0 & -0.179 & $* * *$ & -11.8 \\
\hline Class A & 0.532 & $* * *$ & 10.5 & 0.435 & $* * *$ & 6.3 & 0.421 & $* * *$ & 7.0 & 0.477 & $* * *$ & 9.5 \\
\hline Class B & 0.150 & $* * *$ & 8.5 & 0.129 & $* * *$ & 3.0 & 0.115 & $* * *$ & 3.6 & 0.112 & $* * *$ & 3.6 \\
\hline Multi-tenant & -0.037 & $* *$ & -2.3 & -0.154 & $* * *$ & -4.0 & -0.109 & $* * *$ & -3.6 & -0.123 & $* * *$ & -4.4 \\
\hline $\ln$ (Market time) & -0.032 & $* * *$ & -4.7 & -0.051 & $* * *$ & -3.4 & -0.059 & $* * *$ & -4.8 & -0.051 & $* * *$ & -4.9 \\
\hline Seller rep & -0.027 & & -1.0 & 0.183 & $* *$ & 2.5 & 0.055 & & 0.8 & 0.073 & $* *$ & 2.2 \\
\hline Same rep & -0.107 & $* * *$ & -5.3 & -0.081 & $* *$ & -2.0 & -0.066 & $* *$ & -2.6 & & & \\
\hline Buyer rep & 0.107 & $* * *$ & 6.5 & 0.020 & & 0.6 & & & & & & \\
\hline Nonlocal & & & & & & & 0.071 & $* * *$ & 3.0 & 0.078 & $* * *$ & 3.1 \\
\hline Buyer type & \multicolumn{3}{|c|}{21 indicators } & \multicolumn{3}{|c|}{20 indicators } & \multicolumn{3}{|c|}{20 indicators } & \multicolumn{3}{|c|}{21 indicators } \\
\hline Calendar year & \multicolumn{3}{|c|}{6 indicators } & \multicolumn{3}{|c|}{6 indicators } & \multicolumn{3}{|c|}{6 indicators } & \multicolumn{3}{|c|}{7 indicators } \\
\hline Sale conditions & \multicolumn{3}{|c|}{117 indicators } & \multicolumn{3}{|c|}{61 indicators } & \multicolumn{3}{|c|}{62 indicators } & \multicolumn{3}{|c|}{79 indicators } \\
\hline Market & \multicolumn{3}{|c|}{127 indicators } & \multicolumn{3}{|c|}{92 indicators } & \multicolumn{3}{|c|}{137 indicators } & \multicolumn{3}{|c|}{118 indicators } \\
\hline Adjusted R2 & \multicolumn{3}{|c|}{$56.7 \%$} & \multicolumn{3}{|c|}{$56.5 \%$} & \multicolumn{3}{|c|}{$62.2 \%$} & \multicolumn{3}{|c|}{$53.5 \%$} \\
\hline Observations & & 9024 & & & 2618 & & & 2618 & & & 7490 & \\
\hline
\end{tabular}

Notes: This table presents the results from the estimation of Sale price (\$/SF), logged, for the purchase samples. Propensity-score matched samples are used in each case, consisting of equal number observations for Represented and Unrepresented Buyers (in the Local and Nonlocal subsamples), or equal number of observations for Local and Nonlocal Buyers (in the Represented and Unrepresented subsamples). The variables Land area, Size, Age, and Market time are each logged. The variable name is listed in the first column, the estimated coefficient in the second, and the t-statistic (t-stat) in italics is in the third column. The respective t-statistic and reported significance level are based on standard errors clustered by market and calendar year. All variables are defined in the notes to Table 1. The estimation includes fixed effects indicator variables controlling for buyer type, calendar year of the transaction date, sale conditions, and geographic markets. ${ }^{* *}$ and ${ }^{* *}$ indicate statistical significance of the estimated coefficient based on the corresponding t-statistic at the $1 \%$ and $5 \%$ levels respectively. 
There are at least two possible explanations. The first suggests that brokers have a perverse incentive to maximize transaction price because their compensation structure, as a percentage commission rate, is linearly increasing with price. Perhaps financial incentives for buyer brokers are misaligned with the buyer's objective of minimizing the acquisition price. The second possibility is that selection bias exists for buyers who opt for broker representation. In the CRE investment market, experienced and sophisticated investors may be more likely to forgo the use of a buyer broker. Supplementary evidence in the sample appears to support this explanation. Buyers who use brokers the least (10 percent or less of the time) include listed funds, pension funds, sovereign funds, real estate investment trusts, and real estate operating companies-all relatively sophisticated institutional investors. Buyers who use brokers the most frequently (40 percent of the time or more) are trusts, corporates, educational funds, endowments, and individual buyers. Non-representation thereby functions as a proxy for the pre-existing competitive edge, such as firms with dedicated analysts and in-house CRE research divisions.

While buyer representation appears to convey a disadvantage, use of a broker from the same firm as the listing brokerage exactly offsets this outcome for local buyers. The estimated transaction price is reduced by 10.7 percent when using brokers from the same firm (coefficient for Same rep), subtracted from the 10.7 percent premium for having used a buyer broker in the first place nets to zero. Dual agency has the potential for efficiency gains such as when an internal client is identified as a potential match for the listing-also called internalized transactions. Yet, dual agency also creates the potential for incentive misalignments that stem from informational asymmetries inherent in CRE transactions. Brokers may possess private knowledge regarding the reservation price, motivation, urgency, or constraints of either party. While use of this knowledge may facilitate a more expeditious screening of potential matches, it also exposes the brokerage firm to increased risk of litigation if either party feels treated unfairly after the closing. The perception of heightened litigation risk can serve as a mechanism that encourages brokers who are involved in dual agency transactions to limit the degree to which they might allow a buyer to overpay.

Continuing with the results in Table 3, the second set considers broker representation effects for nonlocal buyers. Use of a buyer broker has zero impact on the price paid by nonlocal investors (coefficient for Buyer rep is insignificant); unless the seller is represented and the buyer happens to use a broker from the same firm. In contrast to the result for local buyers, the presence of a listing agent (or seller representation) has a sizable impact on the transaction price. Seller brokers are able to extract an estimated surplus of 18.3 percent in overpayment (coefficient on Seller rep) from nonlocal buyers. This magnitude is measured relative to prices paid by nonlocal buyers on similar assets when the seller is unrepresented. Thus, buyer brokerage arrangements do not appear to help nonlocal buyers in getting a better price. Instead, listing brokers help the seller to get a better price when the buyer is an informationally disadvantaged 
out-of-towner.

When faced with a seller who has broker representation, the most impactful decision a nonlocal buyer can make is to elect for dual agency and seek out a buyer broker from the same firm of the listing broker. The estimated price impact from dual agency reduces the degree of overpayment for nonlocals by 8.1 percent (coefficient of Same rep)-netting out to 10.2 percent overpayment, versus 18.3 percent in the absence of dual agency. Thus, while the optimal path for a nonlocal buyer is to pursue assets that are marketed by unrepresented sellers, when a seller has broker representation, nonlocal buyers should attempt to hire a broker to represent their own interest from the same firm. If not, the degree of overpayment by nonlocal buyers transacting with a represented seller is 18.3 percent-independent of whether buyer representation exists.

Whereas the first and second sets of results in Table 3 compare broker representation effects, the third and fourth sets compare the estimated difference in prices paid according to buyer origin. Nonlocal investors are similarly disadvantaged regardless of whether they have buyer representation. Nonlocals overpay by an estimated 7.1 percent with buyer representation, and 7.8 percent without. Yet, buyer representation creates an opportunity for potential efficiency gains to occur under dual agency. When the buyer and listing broker are from the same firm, the degree of overpayment for nonlocals is cut down by 6.6 percent. As previously discussed, dual agency is one of the most favorable scenarios for a nonlocal buyer. If the nonlocal buyer decides to go unrepresented in the transaction and the seller has broker representation, the degree of overpayment is 7.8 percent for being a nonlocal plus an additional 7.3 percent premium, extracted from the buyer's willingness-to-pay surplus, which occurs when a CRE broker represents the opposite party.

Table 4 provides complementary results for the sale side of the transaction. Local sellers obtain similar exit prices regardless of broker representation (coefficient on Seller rep is insignificant from zero). If the local seller matches with a represented buyer (a proxy for unsophisticated cohort), then the sale price increases by an estimated 10.1 percent (coefficient on Buyer rep). Although when both parties are represented by the same firm, the degree of overpayment is reduced by 7.9 percent to a net premium of 2.2 percent. In the second set of results in Table 4, broker representation fails to make any meaningful difference for nonlocal sellers. Even if there is buyer representation (previously discussed as potentially disadvantaged group) or dual agency, the difference in sale price is insignificant from zero for nonlocal sellers.

The third and fourth sets of results in Table 4 compare the estimated difference in transaction prices accepted by nonlocals to that of local investors. Nonlocals sell at an estimated discount of 8.1 percent with representation and a discount of 12.0 percent without; this is measured relative to prices on comparable assets sold by local investors. Consistent with other findings in this study, the presence of buyer representation is associated with higher prices and dual agency works to offsets the degree of overpayment for represented buyers. 
Table 4. Estimated price effects: Sales samples.

\begin{tabular}{|c|c|c|c|c|c|c|c|c|c|c|c|c|}
\hline \multirow{3}{*}{$\begin{array}{c}\text { Sample } \\
\text { Variable } \\
\text { Constant }\end{array}$} & \multicolumn{3}{|c|}{ Local Sellers } & \multicolumn{3}{|c|}{ Nonlocal Sellers } & \multicolumn{3}{|c|}{ Represented } & \multicolumn{3}{|c|}{ Unrepresented } \\
\hline & \multicolumn{2}{|c|}{ Coefficient } & \multirow{2}{*}{\begin{tabular}{r|} 
t-stat \\
32.6
\end{tabular}} & \multicolumn{2}{|c|}{ Coefficient } & \multirow{2}{*}{$\begin{array}{r}\text { t-stat } \\
19.1\end{array}$} & \multicolumn{2}{|c|}{ Coefficient } & \multirow{2}{*}{\begin{tabular}{r|} 
t-stat \\
39.5
\end{tabular}} & \multicolumn{2}{|c|}{ Coefficient } & \multirow{2}{*}{\begin{tabular}{c|} 
t-stat \\
10.1
\end{tabular}} \\
\hline & 6.612 & $* * *$ & & 6.769 & $* * *$ & & 6.904 & $* * *$ & & 6.439 & $* * *$ & \\
\hline $\ln ($ Land area $)$ & -0.004 & & -0.4 & -0.048 & $* * *$ & -2.9 & -0.049 & $* * *$ & -6.5 & -0.055 & & -1.5 \\
\hline $\ln ($ Size $)$ & -0.160 & $* * *$ & -13.0 & -0.076 & $* * *$ & -4.1 & -0.071 & $* * *$ & -7.9 & -0.109 & $* * *$ & -2.8 \\
\hline $\ln ($ Age $)$ & -0.126 & $* * *$ & -10.5 & -0.170 & $* * *$ & -8.3 & -0.166 & $* * *$ & -18.3 & -0.129 & $* * *$ & -2.9 \\
\hline Class A & 0.564 & $* * *$ & 9.7 & 0.660 & $* * *$ & 9.0 & 0.571 & $* * *$ & 16.2 & 0.492 & $* * *$ & 3.2 \\
\hline Class B & 0.141 & $* * *$ & 6.2 & 0.131 & $* * *$ & 3.1 & 0.095 & $* * *$ & 5.0 & 0.099 & & 1.1 \\
\hline Multi-tenant & -0.076 & $* *$ & -3.6 & -0.077 & $* *$ & -2.1 & -0.084 & $* * *$ & -4.9 & -0.101 & & -1.3 \\
\hline $\ln$ (Market time) & -0.041 & $* * *$ & -4.7 & -0.042 & $* * *$ & -2.7 & -0.051 & $* * *$ & -7.2 & -0.053 & * & -2.0 \\
\hline Buyer rep & 0.101 & $* * *$ & 4.4 & 0.002 & & 0.1 & 0.048 & $* * *$ & 2.9 & 0.056 & & 0.5 \\
\hline Same rep & -0.079 & $* * *$ & -2.6 & -0.051 & & -1.0 & -0.064 & $* * *$ & -3.1 & & & \\
\hline Seller rep & -0.029 & & -1.1 & -0.006 & & -0.1 & & & & & & \\
\hline Nonlocal & & & & & & & -0.081 & $* * *$ & -5.5 & -0.120 & * & -1.7 \\
\hline Seller type & \multicolumn{3}{|c|}{19 indicators } & \multicolumn{3}{|c|}{20 indicators } & \multicolumn{3}{|c|}{20 indicators } & \multicolumn{3}{|c|}{14 indicators } \\
\hline Calendar year & \multicolumn{3}{|c|}{9 indicators } & \multicolumn{3}{|c|}{6 indicators } & \multicolumn{3}{|c|}{7 indicators } & \multicolumn{3}{|c|}{8 indicators } \\
\hline Sale conditions & \multicolumn{3}{|c|}{81 indicators } & \multicolumn{3}{|c|}{87 indicators } & \multicolumn{3}{|c|}{112 indicators } & \multicolumn{3}{|c|}{38 indicators } \\
\hline Market & \multicolumn{3}{|c|}{115 indicators } & \multicolumn{3}{|c|}{107 indicators } & \multicolumn{3}{|c|}{121 indicators } & \multicolumn{3}{|c|}{85 indicators } \\
\hline Adjusted R2 & \multicolumn{3}{|c|}{$50.7 \%$} & \multicolumn{3}{|c|}{$59.3 \%$} & \multicolumn{3}{|c|}{$59.5 \%$} & \multicolumn{3}{|c|}{$50.9 \%$} \\
\hline Observations & & 8106 & & & 3162 & & & 7750 & & & 3162 & \\
\hline
\end{tabular}

Notes: This table presents the results from the estimation of Sale price (\$/SF), logged, for the sales samples. Propensity-score matched samples are used in each case, consisting of equal number observations for Represented and Unrepresented Sellers (in the Local and Nonlocal subsamples), or equal number of observations for Local and Nonlocal Sellers (in the Represented and Unrepresented subsamples). The variables Land area, Size, Age, and Market time are each logged. The variable name is listed in the first column, the estimated coefficient in the second, and the t-statistic (t-stat) in italics is in the third column. The respective $t$-statistic and reported significance level are based on standard errors clustered by market and calendar year. All variables are defined in the notes to Table 1 . The estimation includes fixed effects indicator variables controlling for seller type, calendar year of the transaction date, sale conditions, and geographic markets. ${ }^{* *}, * *$, and ${ }^{*}$ indicate statistical significance of the estimated coefficient based on the corresponding t-statistic at the $1 \%, 5 \%$, and $10 \%$ levels respectively.

Table 5 presents results from the estimations for marketing duration, reflecting an additional dimension to CRE marketing outcomes. Assets sold via listing brokers experience significantly longer marketing periods. Use of a listing broker increases marketing time by an estimated 18.3 percent for local sellers and by 24.5 percent for nonlocal sellers. The difference in marketing durations for local and nonlocal sellers is insignificant from zero (coefficients on Nonlocal). A seller may elect to not use a listing broker if they believe a willing buyer can be successfully identified through their existing network of CRE contacts. Unbrokered transactions can save money by avoiding the brokerage commission fee, which leaves a positive surplus to be divided between buyer and seller. This motive is plausible as, indeed, unrepresented sellers are significantly more likely to transact 
Table 5. Marketing duration: Sales samples.

\begin{tabular}{|c|c|c|c|c|c|c|c|c|c|c|c|c|}
\hline \multirow{3}{*}{$\begin{array}{c}\text { Sample } \\
\text { Variable } \\
\text { Constant }\end{array}$} & \multicolumn{3}{|c|}{ Local Sellers } & \multicolumn{3}{|c|}{ Nonlocal Sellers } & \multicolumn{3}{|c|}{ Represented } & \multicolumn{3}{|c|}{ Unrepresented } \\
\hline & \multicolumn{2}{|c|}{ Coefficient } & \multirow{2}{*}{$\begin{array}{r}\text {-stat } \\
12.3\end{array}$} & \multicolumn{2}{|c|}{ Coefficient } & \multirow{2}{*}{\begin{tabular}{c|} 
t-stat \\
8.2
\end{tabular}} & \multicolumn{2}{|c|}{ Coefficient } & \multirow{2}{*}{\begin{tabular}{r|} 
t-stat \\
17.5
\end{tabular}} & \multicolumn{2}{|c|}{ Coefficient } & \multirow{2}{*}{$\begin{array}{c}\text { t-stat } \\
4.2\end{array}$} \\
\hline & 5.286 & $* * *$ & & 6.138 & $* * *$ & & 6.277 & $* * *$ & & 6.225 & $* * *$ & \\
\hline $\ln ($ Land area $)$ & 0.026 & & 1.3 & 0.034 & & 1.1 & 0.007 & & 0.5 & 0.039 & & 0.5 \\
\hline $\ln ($ Size $)$ & -0.010 & & -0.4 & -0.005 & & -0.2 & -0.020 & & -1.2 & -0.030 & & -0.4 \\
\hline $\ln ($ Age $)$ & -0.126 & $* * *$ & -5.5 & -0.031 & & -0.8 & -0.120 & $* * *$ & -6.8 & -0.090 & & -0.9 \\
\hline Class A & -0.464 & $* * *$ & -4.2 & -0.509 & $* * *$ & -3.6 & -0.370 & $* * *$ & -5.5 & 0.076 & & 0.2 \\
\hline Class B & 0.055 & & 1.3 & 0.106 & & 1.3 & 0.052 & & 1.5 & 0.227 & & 1.2 \\
\hline Multi-tenant & 0.052 & & 1.3 & -0.091 & & -1.3 & -0.070 & $* *$ & -2.2 & 0.168 & & 1.0 \\
\hline $\ln ($ Sale price $)$ & -0.148 & $* * *$ & -4.7 & -0.151 & $* * *$ & -2.7 & -0.180 & $* * *$ & -7.2 & -0.230 & * & -2.0 \\
\hline Buyer rep & 0.162 & $* * *$ & 3.7 & 0.174 & $* *$ & 2.4 & 0.121 & $* * *$ & 3.9 & 0.111 & & 0.5 \\
\hline Same rep & -0.242 & $* * *$ & -4.2 & -0.088 & & -0.9 & -0.150 & $* * *$ & -4.0 & & & \\
\hline Seller rep & 0.183 & $* * *$ & 3.7 & 0.245 & $* * *$ & 2.9 & & & & & & \\
\hline Nonlocal & & & & & & & -0.040 & & -1.6 & 0.048 & & 0.3 \\
\hline Seller type & \multicolumn{3}{|c|}{19 indicators } & \multicolumn{3}{|c|}{20 indicators } & \multicolumn{3}{|c|}{20 indicators } & \multicolumn{3}{|c|}{14 indicators } \\
\hline Calendar year & \multicolumn{3}{|c|}{9 indicators } & \multicolumn{3}{|c|}{6 indicators } & \multicolumn{3}{|c|}{7 indicators } & \multicolumn{3}{|c|}{8 indicators } \\
\hline Sale conditions & \multicolumn{3}{|c|}{81 indicators } & \multicolumn{3}{|c|}{87 indicators } & \multicolumn{3}{|c|}{112 indicators } & \multicolumn{3}{|c|}{38 indicators } \\
\hline Market & \multicolumn{3}{|c|}{115 indicators } & \multicolumn{3}{|c|}{107 indicators } & \multicolumn{3}{|c|}{121 indicators } & \multicolumn{3}{|c|}{85 indicators } \\
\hline Adjusted R2 & \multicolumn{3}{|c|}{$14.6 \%$} & \multicolumn{3}{|c|}{$25.8 \%$} & \multicolumn{3}{|c|}{$15.6 \%$} & \multicolumn{3}{|c|}{$34.4 \%$} \\
\hline Observations & & 8106 & & & 3162 & & & 7750 & & & 3162 & \\
\hline
\end{tabular}

Notes: This table presents the results from the estimation of Market time, logged, for the sales samples. Propensity-score matched samples are used in each case, consisting of equal number observations for Represented and Unrepresented Sellers (in the Local and Nonlocal subsamples), or equal number of observations for Local and Nonlocal Sellers (in the Represented and Unrepresented subsamples). The variables Land area, Size, Age, and Sale price are each logged. The variable name is listed in the first column, the estimated coefficient in the second, and the t-statistic (t-stat) in italics is in the third column. The respective $\mathrm{t}$-statistic and reported significance level are based on standard errors clustered by market and calendar year. All variables are defined in the notes to Table 1 . The estimation includes fixed effects indicator variables controlling for seller type, calendar year of the transaction date, sale conditions, and geographic markets. ${ }^{* *}, * *$, and ${ }^{*}$ indicate statistical significance of the estimated coefficient based on the corresponding t-statistic at the $1 \%, 5 \%$, and $10 \%$ levels respectively.

with unrepresented buyers (represents 92 percent of transactions in the unrepresented seller sample). In a related manner, dual agency is occasionally referred to as "internalized" transactions, due to the increased likelihood that a buyer is matched from the established network of the listing brokerage firm. Dual agency appears to significantly reduce marketing duration for local sellers.

\section{Conclusions}

Brokers fail to play the intended role, at least on behalf of uninformed parties. Buyer representation has no detectable impact on prices paid by nonlocal investors-the proxy group for informationally-disadvantaged. Nonlocal buyers pay significant premiums, in the magnitude of 7 to 8 percent, regardless of broker 
representation. Seller representation also has no meaningful impact on price. Sale prices attained by nonlocals are not significantly different when a listing broker is involved, even though marketing durations are considerably longer. These findings confirm a pronounced clientele effect for nonlocal investors in CRE markets-one that is largely unaffected by brokerage intermediation. Either brokers do not possess specialized market information that might be used to offset the informational disadvantages faced by their clients, or they neglect to effectively deploy such knowledge. Impactful information for a particular transaction may be elusive due to the highly heterogeneous nature of CRE assets. Withholding such information may occur when brokerage incentives are misaligned with the principal.

Whereas the informational role appears limited when brokers act on behalf of uninformed investors, the bargaining role appears with distinction when brokers represent the party opposite to uninformed investors. The degree of overpayment is significantly higher for nonlocal buyers when the seller is represented by a broker. Yet, when opposing local buyers, a broker-represented seller is unable to have a significant impact on selling price. Thus, brokers are able to extract willingness-to-pay surplus from uninformed buyers only.

The mitigating circumstance to all of the above detrimental outcomes for nonlocal investors occurs under dual agency, where the same brokerage firm represents both buyer and seller and litigation risk is amplified. Under dual agency, the degree of overpayment is significantly reduced for all disadvantaged buyers. This result suggests that brokers are likely to possess privileged information about investor reservation prices, rather than market values. Knowing both informed and uninformed investor expectations, dual agency brokers are able to facilitate more favorable outcomes for uninformed investors.

Nonetheless, the belief that brokers possess a high degree of specialized market knowledge that can act to offset informational disadvantages faced by either party is widely endorsed. We find little evidence to support this notion. Nonlocal investors are persistent underperformers in the markets for CRE investments, with and without brokers, suggesting that there are practical limitations to theoretically-optimal geographic diversification within CRE portfolios.

\section{Conflicts of Interest}

The authors declare no conflicts of interest regarding the publication of this paper.

\section{References}

[1] Miller, N.G., Sklarz, M.A. and Ordway, N. (1988) Japanese Purchases, Exchange Rates and Speculation in Residential Real Estate Markets. Journal of Real Estate Research, 3, 39-49.

[2] Vrooman, D.H. (1978) An Empirical Analysis of Determinants of Land Values in the Adirondack Park. American Journal of Economics and Sociology, 37, 165-177. https://doi.org/10.1111/j.1536-7150.1978.tb02811.x

[3] Simonsohn, U. and Loewenstein, G. (2006) Mistake \#37: The Effect of Previously Encountered Prices on Current Housing Demand. The Economic Journal, 116, 
175-199. https://doi.org/10.1111/j.1468-0297.2006.01052.x

[4] Neo, P.H., Ong, S.E. and Tu, Y. (2008) Buyer Exuberance and Price Premium. Urban Studies, 45, 331-345. https://doi.org/10.1177/0042098007085966

[5] Clauretie, T. and Thistle, P. (2007) The Effect of Time-on-Market and Location on Search Costs and Anchoring: The Case of Single-Family Properties. Journal of Real Estate Finance and Economics, 35, 181-196. https://doi.org/10.1007/s11146-007-9034-x

[6] Turnbull, G.K. and Sirmans, C.F. (1993) Information, Search, and House Prices. Regional Science and Economics, 23, 545-557.

https://doi.org/10.1016/0166-0462(93)90046-H

[7] Watkins, C. (1998) Are New Entrants to the Residential Property Market Informationally Disadvantaged? Journal of Property Research, 15, 57-70.

https://doi.org/10.1080/095999198368509

[8] Ihlanfeldt, K. and Mayock, T. (2012) Information, Search, and House Prices: Revisited. Journal of Real Estate Finance and Economics, 44, 90-115. https://doi.org/10.1007/s11146-010-9282-Z

[9] Lambson, V.E., McQueen, G.R. and Slade, B.A. (2004) Do Out-of-Market Buyers Pay More for Real Estate? An Examination of Anchoring-Induced Bias and Search Costs. Real Estate Economics, 32, 85-126. https://doi.org/10.1111/j.1080-8620.2004.00085.x

[10] Liu, Y., Gallimore, P. and Wiley, J.A. (2014) Nonlocal Office Investors: Anchored by Their Markets and Impaired by Their Distance. Journal of Real Estate Finance and Economics, 50, 129-149. https://doi.org/10.1007/s11146-013-9446-8

[11] Han, L. and Strange, W.C. (2014) The Microstructure of Housing Markets: Search, Bargaining, and Brokerage. In: Duranton, G., Henderson, V. and Strange, W.C., Eds., Handbook of Regional and Urban Economics, Vol. 5, Elsevier, Amsterdam, 813-886. https://doi.org/10.1016/B978-0-444-59531-7.00013-2

[12] Geltner, D., Kluger, B.D. and Miller, N.G. (1991) Optimal Price and Selling Effort from the Perspective of the Broker and Seller. Real Estate Economics, 19, 1-24. https://doi.org/10.1111/1540-6229.00537

[13] Bernheim, B.D. and Meer, J. (2013) Do Real Estate Brokers Add Value When Listing Services Are Unbundled? Economic Inquiry, 51, 1166-1182. https://doi.org/10.1111/j.1465-7295.2012.00473.x

[14] Rutherford, R.C., Springer, T.M. and Yavas, A. (2005) Conflicts between Principals and Agents: Evidence from Residential Brokerage. Journal of Financial Economics, 76, 627-665. https://doi.org/10.1016/j.jfineco.2004.06.006

[15] Levitt, S.D. and Syverson, C. (2008) Market Distortions When Agents Are Better Informed: The Value of Information in Real Estate Transactions. The Review of Economics and Statistics, 90, 599-611. https://doi.org/10.1162/rest.90.4.599

[16] Yavas, A. and Colwell, P. (1999) Buyer Brokerage: Incentive and Efficiency Implications. Journal of Real Estate Finance and Economics, 18, 259-277. https://doi.org/10.1023/A:1007733916238

[17] Zietz, J. and Newsome, B. (2001) A Note on Buyer's Agent Commission and Sale Price. Journal of Real Estate Research, 21, 245-253.

[18] Gardiner, J., Heisler, J., Kallberg, J.G. and Liu, C.H. (2007) The Impact of Dual Agency. Journal of Real Estate Finance and Economics, 35, 39-55. https://doi.org/10.1007/s11146-007-9028-8

[19] Hardin, W.G., Johnson, K.H. and $\mathrm{Wu}, \mathrm{Z}$. (2009) Broker Intermediation in the Commercial Property Market. Journal of Real Estate Research, 31, 397-420. 


\section{Appendix}

Table A1. Probit for propensity-scores.

\begin{tabular}{|c|c|c|c|c|c|c|c|c|c|c|c|c|}
\hline \multirow{4}{*}{$\begin{array}{c}\text { Panel A. Purchases } \\
\text { Dependent } \\
\text { Variable } \\
\text { Constant }\end{array}$} & \multicolumn{3}{|c|}{ Local Buyers } & \multicolumn{3}{|c|}{ Nonlocal Buyers } & \multicolumn{3}{|c|}{ Represented } & \multicolumn{3}{|c|}{ Unrepresented } \\
\hline & \multicolumn{3}{|c|}{ Buyer rep } & \multicolumn{3}{|c|}{ Buyer rep } & \multicolumn{3}{|c|}{ Nonlocal buyer } & \multicolumn{3}{|c|}{ Nonlocal buyer } \\
\hline & \multicolumn{2}{|c|}{ Coefficient } & \multirow{2}{*}{$\frac{(\text { Wald X2) }}{(5.7)}$} & \multicolumn{2}{|c|}{ Coefficient } & \multirow{2}{*}{$\frac{(\text { Wald X2) }}{(0.5)}$} & \multicolumn{2}{|c|}{ Coefficient } & \multirow{2}{*}{$\frac{(\text { Wald X2) }}{(39.1)}$} & \multicolumn{2}{|c|}{ Coefficient } & \multirow{2}{*}{$\frac{(\text { Wald X2) }}{(123.7)}$} \\
\hline & -0.629 & $* *$ & & 0.264 & & & -2.640 & $* * *$ & & -2.850 & $* * *$ & \\
\hline $\ln ($ Land area $)$ & 0.004 & & $(0.1)$ & 0.017 & & $(0.5)$ & 0.061 & $* *$ & (5.8) & 0.047 & $* * *$ & $(9.0)$ \\
\hline $\ln ($ Size $)$ & 0.041 & $* *$ & $(6.0)$ & -0.030 & & (1.5) & 0.213 & $* * *$ & $(46.9)$ & 0.177 & $* * *$ & $(92.5)$ \\
\hline $\ln ($ Age $)$ & -0.039 & $* *$ & (5.3) & -0.060 & * & (3.7) & -0.070 & $* *$ & (5.2) & 0.019 & & $(0.9)$ \\
\hline Class A & -0.227 & $* * *$ & $(9.8)$ & -0.170 & & (2.6) & 0.016 & & $(0.0)$ & 0.042 & & $(0.4)$ \\
\hline Class B & 0.077 & $* *$ & $(6.0)$ & 0.029 & & $(0.2)$ & 0.010 & & $(0.0)$ & 0.030 & & $(0.5)$ \\
\hline Multi-tenant & -0.060 & $* *$ & $(4.2)$ & 0.038 & & $(0.4)$ & -0.080 & & (1.9) & -0.100 & $* * *$ & $(7.2)$ \\
\hline Buyer type & \multicolumn{3}{|c|}{22 indicators } & \multicolumn{3}{|c|}{22 indicators } & \multicolumn{3}{|c|}{21 indicators } & \multicolumn{3}{|c|}{23 indicators } \\
\hline Calendar year & \multicolumn{3}{|c|}{17 indicators } & \multicolumn{3}{|c|}{14 indicators } & \multicolumn{3}{|c|}{11 indicators } & \multicolumn{3}{|c|}{16 indicators } \\
\hline Sale conditions & \multicolumn{3}{|c|}{231 indicators } & \multicolumn{3}{|c|}{143 indicators } & & indic & ators & & indi & ators \\
\hline Market & & 5 ind & cators & & 6 indi & ators & & indi & ators & & indi & ators \\
\hline Pseudo-R2 & & 13.6 & & & 25.5 & & & 32.6 & & & 37.4 & \\
\hline Observations & & 12,1 & & & 5,05 & & & 5,82 & & & 11,3 & \\
\hline Panel B. Sales & & cal s & ellers & & local & Sellers & & prese & ated & & cepre & ented \\
\hline Dependent & & Selles & rep & & Seller & & & local & seller & & nloca & seller \\
\hline Variable & Coeffici & ent & (Wald X2) & Coeffic & & (Wald X2) & Coeffici & & (Wald X2) & Coeffici & & (Wald X2) \\
\hline Constant & 0.362 & & (1.7) & 1.158 & $* * *$ & $(10.7)$ & -2.634 & $* * *$ & $(70.9)$ & 1.158 & $* * *$ & $(44.0)$ \\
\hline $\ln ($ Land area $)$ & -0.049 & $* * *$ & (12.7) & -0.006 & & $(0.1)$ & 0.073 & $* * *$ & $(23.0)$ & -0.006 & & $(0.1)$ \\
\hline $\ln ($ Size $)$ & -0.050 & $* * *$ & (8.9) & -0.065 & $* * *$ & $(6.8)$ & 0.151 & $* * *$ & $(68.2)$ & -0.065 & $* * *$ & $(52.4)$ \\
\hline $\ln ($ Age $)$ & 0.016 & & $(0.9)$ & 0.010 & & $(0.1)$ & 0.086 & $* * *$ & $(21.9)$ & 0.010 & $* *$ & (4.5) \\
\hline Class A & 0.190 & $* * *$ & (7.3) & 0.273 & $* * *$ & (8.7) & 0.091 & & (1.8) & 0.273 & & $(0.0)$ \\
\hline Class B & 0.026 & & $(0.6)$ & 0.102 & * & (2.9) & 0.073 & * & (3.5) & 0.102 & & $(0.1)$ \\
\hline Multi-tenant & -0.059 & * & (3.7) & -0.024 & & $(0.2)$ & -0.072 & $* *$ & (4.3) & -0.024 & $* *$ & (5.3) \\
\hline Seller type & & indi & ators & & indic & tors & & indic & tors & & indic & ators \\
\hline Calendar year & & $t$ indi & ators & & indic & tors & & indic & tors & & indic & ators \\
\hline Sale conditions & & 2 ind & cators & & indic & ators & & indic & ators & & indi & ators \\
\hline Market & & 4 ind & cators & & indic & ators & & indic & ators & & indi & ators \\
\hline Pseudo-R2 & & 13.8 & & & 20.5 & & & 28.5 & & & 29.3 & \\
\hline Observations & & 11,5 & & & 545 & & & 11,36 & & & 563 & \\
\hline
\end{tabular}

Notes: This table presents the results from the probit estimation for investor identity according to subsamples for local investors (dependent variable is Buyer rep or Seller rep), nonlocal investors (dependent variable is Buyer rep or Seller rep), represented investors (dependent variable is Nonlocal), and unrepresented investors (dependent variable is Nonlocal). Panel A provides results for the purchase samples; Panel B for the sales samples. The variables Land area, Size, and Age are each logged. The variable name is listed in the first column, the estimated Coefficient in the second, and the Wald $X^{2}$ test statistic (in parentheses) is in the third column. All variables are defined in the notes to Table 1. The estimation includes fixed effects indicator variables controlling for investor type, calendar year of the transaction date, sale conditions, and geographic markets. ${ }^{* * *}$, ${ }^{* *}$, and ${ }^{*}$ indicate statistical significance of the estimated coefficient based on the corresponding Wald-statistic at the $1 \%, 5 \%$, and $10 \%$ levels respectively. Results from the estimations shown in this table are used to generate the respective propensity-score matched samples shown in Table 1 and Table 2. 